\title{
Perception of selected sportswear brands with emphasis on expected benefits and features as prerequisite for customer satisfaction
}

\author{
Katarina Janoskova ${ }^{1, *}$, Pavol $\mathrm{Kral}^{2}$ \\ ${ }^{1}$ University of Žilina, Faculty of Operation and Economics of Transport and Communications, \\ Department of Economics, Univerzitna 8215/1, 01026 Žilina, Slovakia \\ ${ }^{2}$ University of Žilina, Faculty of Operation and Economics of Transport and Communications, \\ Department of Economics, Univerzitna 8215/1, 01026 Žilina, Slovakia
}

\begin{abstract}
Brand management has an important role in strengthening the loyalty of current customers as well as in attracting new customers. The product brand largely influences consumer buying behaviour. Many customers prefer branded products to non-branded goods in general, while others prefer branded products only when buying some kinds of products. This research is focused on analysis of perception of selected brands of sportswear (Nike, Adidas, Reebok, Under Armour, Puma, Asics, Umbro, Fila, Crivit, Quiksilver) by Slovak customers with an emphasis on expected benefits and features that are expected after buying preferred sportswear brand. The aim of research is to analyse the relationship between selected socio-demographic characters of Slovak citizens (age, gender, economic status, net monthly income, education) and their expected benefits of selected sportswear brands (happiness, lifestyle, attention, finding friend, increasing of social status). The relationship between selected factors was tested on a sample of 2002 respondents from Slovak republic. Information on perception of sportswear brand has been obtained through a survey. The results of the survey were evaluated using appropriate mathematical-statistical methods (correlation analysis, testing of statistical hypotheses). The assumption of a significant impact of the socio-demographic characteristics of the respondents on the expected benefits was confirmed partially.
\end{abstract}

\section{Introduction}

Fashion and textile is one of the most growing industries. The global market for sportswear is tremendously booming because of the rising participation in sports activities throughout the predicted period. In 2018, the global sportswear market size was 84100 million US\$ and is forecast to 108700 million US\$ in 2025, growing at a compound annual growth rate of $3.3 \%$ from 2018 . There is no doubt that the textile and fashion

\footnotetext{
*Corresponding author: katarina.janoskova@fpedas.uniza.sk
} 
industries are growing extremely fast. The textile industry is also one of the most pollutants releasing industries of the world. This industry is the cause of water pollution, toxic chemical use and textile waste. Therefore, these industries are area of interest of many authors.

Donmez \& Alp deal with the reasons for the brand preferences and preferences of young consumers who are university students in Turkey for the sports apparel sector using the hidden Markov model based on Markov chains [1]. Similar study was realized by Baek et al. on the sample of college students at two universities in a metropolitan city of South Korea [2]. Wang \& Shen deal with the outdoor sportswear brands from the view of ecodesigned fashion products [3].

The brand is, in fact, a factor that significantly affects the buying decision of the consumer [4] and their satisfaction. Customer satisfaction affects customer loyalty that was the main object of researches realized by many authors. E. g. study of Erdumlu et al. explored the socio-demographic profile of sportswear consumers in Turkey through and analysed their loyalty towards the leading sportswear brands they mostly prefer [5]. Brand loyalty toward sportswear products was also the main aim of the study realized by $\mathrm{Lu} \mathrm{\&} \mathrm{Xu}$ [6]. Dawes in his study investigated brand loyalty and other brand performance metrics in the UK sportswear market [7]. Qian \& Shao presented results of research whose aim was to explore how young Chinese consumers perceive and buy western-branded sportswear and to evaluate their perceptions of western and national sportswear brands based on factors: design, innovation, and quality [8].

Many authors focused on the environmental pollution issues [9-13]. Most of them deal with the environmental problems of textile industry in China, because the textile industry in China is the largest in the world in both overall production and exports.

Customer attitudes represent a significant motivating determinant that leads consumers to a certain type of behaviour. Customer attitudes reflect the consumer's internal feelings (positive or negative) in relation to the brand. Consumer attitudes cannot be directly observed, but can be derived from how the consumer behaves and communicates. Creation of attitudes is conditioned by the direct experience with the brand and information that consumer receive from available communication resources. Product categories and brand can either be predominantly functional of symbolic (e.g. sportswear). Our research is focused on the symbolic and behavioural meaning that cars carry. It is not focused on vehicle technical parameters, but on expectations, attitudes, benefits, level of customer satisfaction, etc.

\section{Methodologies}

A marketing survey was carried out to determine the preferences, attitudes and expectations of Slovak consumers toward sportswear brands. Aim of the survey identified key endogenous and exogenous factors determining the consumers' preferences for the sportswear brands.

The survey was carried out as a part of the long-term research task, which was to work out the integrated financial-behavioural model for brand management to aid brand building in the specific conditions of the Slovak Republic. The survey findings point to the brand positioning specificities, the specificities of consumer psychological profiles as well as the mechanisms of consumer decision-making about products.

The survey sample involved Slovak consumers, regardless of gender, social status, monthly income or place of residence. The collection of the data took place in March 2018. The only restriction in terms of the socio-demographics was set on the age of respondents, i. e. the minimum age of 16 . 
The questionnaire contained 34 questions, mostly the closed-ended (selective) questions, which tend to be more preferred by most respondents. The questionnaire was divided into three parts from the point of view of the context, and which are as follows: the first part dealing with consumer preferences and attitudes towards brands in general, the second part addressing specific cost-saving scenarios in 4 selected areas: automobiles, banks, cola drinks and sportswear; and the last one mapping the socio-demographic characteristics of consumers (tab. 1). This paper is focused only on one part of the questionnaire that investigates consumer preferences toward sportswear brands.

Table 1.Basic characteristics of the sample of respondents

\begin{tabular}{|c|c|c|c|c|c|c|}
\hline \multirow{2}{*}{ Gender } & \multicolumn{3}{|c|}{ male } & \multicolumn{3}{|c|}{ female } \\
\hline & \multicolumn{3}{|c|}{$985(49 \%)$} & \multicolumn{3}{|c|}{$1017(51 \%)$} \\
\hline \multirow{2}{*}{ Age } & $16-25$ & $26-35$ & $36-45$ & $46-55$ & 55 - 65 & 66 and more \\
\hline & $438(22 \%)$ & $423(21 \%)$ & $377(19 \%)$ & $381(19 \%)$ & $293(15 \%)$ & $90(4 \%)$ \\
\hline \multirow{2}{*}{ Education } & \multicolumn{2}{|c|}{ primary/vocational } & \multicolumn{2}{|c|}{ secondary } & \multicolumn{2}{|c|}{ university } \\
\hline & \multicolumn{2}{|c|}{$1071(53 \%)$} & \multicolumn{2}{|c|}{$687(34 \%)$} & \multicolumn{2}{|c|}{$244(12 \%)$} \\
\hline \multirow{2}{*}{ Status } & student & employed & unemployed & $\begin{array}{c}\text { self- } \\
\text { employed }\end{array}$ & retired & $\begin{array}{c}\text { maternity } \\
\text { leave }\end{array}$ \\
\hline & $330(16 \%)$ & $965(48 \%)$ & $128(6 \%)$ & $123(6 \%)$ & $314(16 \%)$ & $142(7 \%)$ \\
\hline \multirow{2}{*}{$\begin{array}{l}\text { Net monthly } \\
\text { household } \\
\text { income }\end{array}$} & up to $500 €$ & $501-1000 €$ & $1001-1500 €$ & $\begin{array}{c}1501-2000 \\
€\end{array}$ & $\begin{array}{l}2001- \\
2500 €\end{array}$ & over $2500 €$ \\
\hline & $342(17 \%)$ & $692(35 \%)$ & $558(28 \%)$ & $255(13 \%)$ & $88(4 \%)$ & $67(3 \%)$ \\
\hline
\end{tabular}

Source: own processing

Mathematical-statistical apparatus was used to meet research aims. The verification of the hypothesis was carried out using the Chi-Square test (IBM SPSS Statistics, ver. 25). Pearson's chi-squared test of independence is tested at the significance level of 0.05 . If the test confirms dependence between the variables, its intensity was measured using the Cramer's V coefficient and Contingency Coefficient, which are the most used contingency rates. The resulting values of Cramer's V coefficient and Contingency Coefficient then distinguishes three degrees of dependence: i) a low dependence - value is between 0 and 0.3 ; ii) a medium dependence - the value of 0.3 - 0.8 and, iii) a strong dependence - value from 0.8 to 1 . The independence test benchmark criteria were met in all the cases; one of the questions, however, had to be answered on the rating scale 1 to 5 ( 1 - completely disagree, 3 - rather neutral, 5 - absolutely agree; where 1 to 2 imply rather a negative attitude, and, otherwise, 4 to 5 imply rather positive attitude towards the branded product), which was to benchmark the statistical hypotheses, that were tested afterwards, using the independence test.

\section{Results and discussion}

\subsection{The most influential sportswear brand}

In order to determine the ranking of sportswear brands based on their impact on respondents' buying behaviour, the top ten best-selling sportswear brands on the domestic market were selected. 


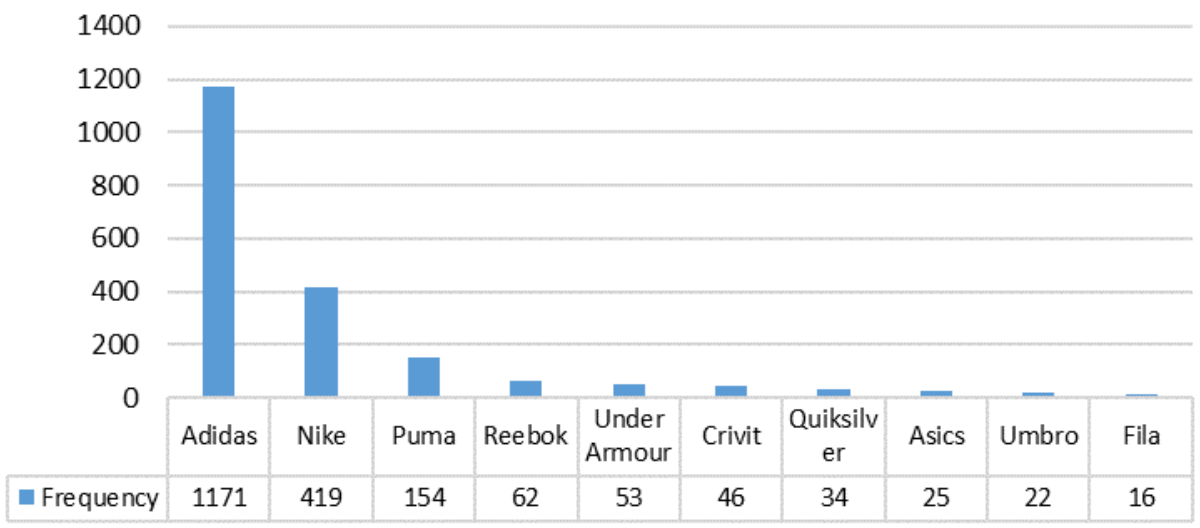

Fig. 1. Sportswear brands rank.

Source: Authors' own research.

We can see in the graph (fig. 1) that the most significant brands is primarily Adidas. Other brands are lagging behind this one major player on the Slovak market. We can see huge differences between frequencies.

\subsection{The impact of socio-demographic characteristics on expected benefits}

In order to test the impact of selected socio-demographic characteristics on expected benefits (benefits that are expected after buying preferred sportswear brand) the hypothesis was formulated:

H0: There is no dependency between the selected socio-demographic character (age/gender/economic status/net monthly income/education) and the expected benefit (happiness, increasing social status, finding friend easier, attracting attention, and part of a lifestyle).

H1: There is a dependency between the selected socio-demographic character (age/gender/economic status/net monthly income/education) and the expected benefit (happiness, increasing social status, finding friend easier, attracting attention, part of a lifestyle).

Overall, there were 25 hypotheses tested by the Chi-square test using IBM SPSS Statistics version 25 software. Outputs are in the following summary table (tab. 2) due to a large number of hypotheses. Hypotheses were tested on the level of significance $\alpha=0.05$. 
Table 2. Testing the dependence between socio-demographic characteristics and expected benefits

\begin{tabular}{|c|c|c|c|c|c|c|}
\hline \multirow{2}{*}{ Expected bene } & & \multicolumn{5}{|c|}{ Socio-demographic data } \\
\hline & fit & \multirow{2}{*}{$\begin{array}{c}\begin{array}{c}\text { Gender } \\
\text { (A1) }\end{array} \\
\text { low }\end{array}$} & \multirow{2}{*}{$\begin{array}{l}\begin{array}{l}\text { Age } \\
\text { (A2) }\end{array} \\
\text { low }\end{array}$} & \multirow{2}{*}{$\begin{array}{c}\begin{array}{c}\text { Economic } \\
\text { status } \\
(\mathbf{A 3})\end{array} \\
\text { low }\end{array}$} & \multirow{2}{*}{ 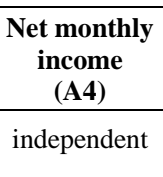 } & \multirow{2}{*}{$\begin{array}{c}\begin{array}{c}\text { Education } \\
\text { (A5) }\end{array} \\
\text { low }\end{array}$} \\
\hline $\begin{array}{l}\text { Makes me } \\
\text { hapnier }\end{array}$ & Degree of correlation & & & & & \\
\hline (B1) & Statistical significance & yes & yes & yes & - & yes \\
\hline & Cramer's $V$ & 0.076 & 0.070 & 0.066 & - & 0.068 \\
\hline & Contingency Coefficient & 0.075 & 0.139 & 0.132 & - & 0.095 \\
\hline \multirow{4}{*}{$\begin{array}{l}\text { Increases my } \\
\text { social status } \\
\text { (B2) }\end{array}$} & Degree of correlation & low & independent & independent & independent & low \\
\hline & Statistical significance & yes & - & - & - & yes \\
\hline & Cramer's $V$ & 0.098 & - & - & - & 0.085 \\
\hline & Contingency Coefficient & 0.097 & - & - & - & 0.119 \\
\hline \multirow{4}{*}{$\begin{array}{l}\text { Makes easier } \\
\text { to find } \\
\text { friends } \\
\text { (B3) }\end{array}$} & Degree of correlation & low & low & independent & low & low \\
\hline & Statistical significance & yes & yes & - & yes & yes \\
\hline & Cramer's $V$ & 0.115 & 0.083 & - & 0.065 & 0.091 \\
\hline & Contingency Coefficient & 0.114 & 0.163 & - & 0.129 & 0.128 \\
\hline \multirow{4}{*}{$\begin{array}{l}\text { Attracts } \\
\text { attention } \\
\text { (B4) }\end{array}$} & Degree of correlation & low & independent & independent & independent & low \\
\hline & Statistical significance & yes & - & - & - & yes \\
\hline & Cramer's $V$ & 0.089 & - & - & - & 0.075 \\
\hline & Contingency Coefficient & 0.089 & - & - & - & 0.106 \\
\hline \multirow{4}{*}{$\begin{array}{l}\text { Belong to my } \\
\text { lifestyle } \\
\text { (B5) }\end{array}$} & Degree of correlation & low & low & low & low & low \\
\hline & Statistical significance & yes & yes & yes & yes & yes \\
\hline & Cramer's $V$ & 0.081 & 0.089 & 0.073 & 0.072 & 0.075 \\
\hline & Contingency Coefficient & 0.080 & 0.174 & 0.145 & 0.142 & ,106 \\
\hline
\end{tabular}

Source: Authors' own research.

Our assumptions have been confirmed only partially because we assumed that expected benefits are significantly affected by socio-demographic characteristics like age, gender, economic status, net monthly income and education. However, low dependence has been confirmed only for some variables (A1/B1, A1/B2, A1/B3, A1/B4, A1/B5, A2/B1, A2/B3, A2/B5, A3, B1, A3/B5, A4/B3, A4/B5, A5/B1, A5/B2, A5/B3, A5/B4, A5/B5). The most influential socio-demographic characteristics are gender and education, where we can see some low influences on the expected benefits (happiness, increasing of social status, finding friends, attention and lifestyle). Although this effect is low but statistically significant, i. e. it is not a random phenomenon.

We assume that customers are affected by key factors motivate them to focus on the selected sportswear brand. These factors are expected benefits such as happiness or lifestyle. 


\section{Conclusions}

Here is no doubt that the textile and fashion industry is one of the most growing industry. Consumers usually prefer some kind of sportswear brand. This preference is affected by attitudes of consumers. Customer attitudes represent a significant motivating determinant that leads consumers to a certain type of behaviour. Customer attitudes reflect the consumer's internal feelings (positive or negative) in relation to the brand. Consumer attitudes cannot be directly observed but can be derived from how the consumer behaves and communicates. Creation of attitudes is conditioned by the direct experience with the brand and information that consumer receives from available communication resources [14]. Based on the results of our survey, we can say that the sportswear brand with greatest impact on the purchasing behaviour of Slovak customers is Adidas. It is very important to mention that there are huge differences between brands. The second brand is Nike with more than 750 losses (in frequency) after the first Adidas. Other brands have the opportunity to increase their impact on consumers. Textile industry is one of the most polluters over the world. Many consumers are very interested in the concept of triple bottom line (so called concept 3P: people, planet, profit) and environmental issues are one part of this principles of corporate social responsibility [15-17]. Future success of sportswear brands will depend only on sportswear brand's ability to flexible respond to the problem of environmental pollution.

We assumed that consumers' expected benefits are closely related to their sociodemographic characteristics. But the assumption of a significant impact of the sociodemographic characteristics (age, gender, economic status, education and net monthly income) on the expected benefits (makes me happier, increases my social status, makes easier to find friends, attracts attention and belong to my lifestyle) was confirmed partially. Statistically significant correlation was confirmed only in some cases, and it was a very low dependence.

\section{Acknowledgments}

This research was financially supported by the Slovak Research and Development Agency - Grant No.APVV-15-0505: Integrated model of management support for building and managing the brand value in the specific conditions of the Slovak Republic.

\section{References}

1. I. Donmez, S. Alp, Application of hidden Markov model for brand preferences and reasons of preferences in sportswear sector. Pamukkale University Journal of Engineering Sciences, 25, 115-120 (2019).

2. WY. Baek, KK. Byon, YH. Choi, CW. Park, Millennial conusmers' perception of sportswear brand globalness impacts purchase intention in cause-related product marketing. Social behaviour and personality, 45, 1319-1335 (2017).

3. L. Wang, B. Shen, A Product Line Analysis for Eco-Designed Fashion Products: Evidence from an Outdoor Sportswear Brand. Sustainability, 9, 1136 (2017).

4. M. Gogolova, J. Majerova, Analysis of the Communication Policy of Car Brand Skoda in the Slovak Market. Proceedings form the 2nd International Conference on Management Innovation and Business Innovation, 44, 9-+ (2014). 
5. N. Erdumlu, C. Saricam, M. Tufekyapan, M. Cetinkaya, AC. Donmez, Analysing the consumer behaviour and the influence of brand loyalty in purchasing sportswear products. Materials Science and Engineering, 254 (2017).

6. JZ. Lu, YJ. Xu, Chinese young consumers' brand loyalty toward sportswear products: a perspective of self-congruity. Journal of product and brand management, 24, 365376 (2015).

7. J. Dawes, Brand loyalty in the UK sportswear market. International Journal of Market Research, 51, 449-463 (2009).

8. JX. Qian, XY. Shao, Young Consumers' Perceptions and Buying Behaviour of Western-branded Sportswear: a Shanghai Study. Textile bioengineering and informatics symposium proceedings, 361-371 (2015).

9. L. Chen, F. Caro, Ch. Corbett et al., Estimating the environemental and economic impacts of wides pread adoption of potential technology solutions to reduce water use and pollution: Application to China's textile industry. Environmental Impact Assessment Review, 79, 106293 (2019).

10. H. Zhao, X. Lu, Z. Shao, Empirical Analysis on Relationship between Water Footprint of China's Textile Industry and Eco-environmnet. Ekoloji, 28, 1067-1076 (2019).

11. H. Zhao, B. Lin, Assesing the energy productivity of China's textile industry under carbon emission constraints. Journal of Cleaner Production, 228, 197-207 (2019).

12. H. Zhao, B. Lin, Resources allocation and more efficient use of energy in China's textile industry. Energy, 185, 111-120 (2019).

13. M. Mumtaz, Y. Bao, W. Li et al. , Screening of textile finishing agents available on the Chinese market: An important source of per- and polyfluoroalkyl substance to the environment. Frontiers of Environmental Science \& Engineering, 13, 67 (2019).

14. I. Moons, P. de Pelsmacker, Self-Brand Personality Differences and Attitudes towards Electric Cars. Sustainability, 7, 12322-12339 (2015).

15. M. Nadanyiova, P. Durana, Corporate social responsibility as a brand value-enhancing tool. $8^{\text {th }}$ International Scientific Symposium Economy of Eastern Croatia - Vision and Growth, 1225-1237 (2019).

16. E. Gregova, K. Kramarova, V.V. Dengov, Significance of the Corporate Social Reposnsibility at National and International Level. International Conference on Information and Business Management, 61, 9-15 (2016).

17. A. Krizanova, L. Gajanova, M. Nadanyiova, Design of a CRM Level and Performance Measurement Model. Sustainability, 10, 2567 (2018). 